\title{
POTENSI PETANI IKAN DALAM MODIFIKASI MENU GIZI KELUARGA UNTUK MENCEGAH KEJADIAN STUNTING PADA BALITA DENGAN PENDEKATAN FTAD (FARMERS TEAM ACHIEVEMENT DIVISION)
}

\author{
Atikah Rahayu ${ }^{1}$, Parida Rahmi ${ }^{2}$, Lia Anggraini ${ }^{3}$ M. Anshori Rahman ${ }^{4}$ \\ ${ }^{1,2,3}$ Departemen Gizi Program Studi Kesehatan Masyarakat, Fakultas Kedokteran, Universitas Lambung \\ Mangkurat, Banjarmasin, Indonesia, ${ }^{4}$ mahasiswa Program Studi Kesehatan Masyarakat, Fakultas \\ Kedokteran, Universitas Lambung Mangkurat, Banjarmasin, Indonesia \\ Email korespondensi: nindya.fitria@gmail.com
}

\begin{abstract}
The implication of a long malnutrition in baduta called stunting, the impact will experience growth barriers / height according to age and brain development so that there is a chance of losing the next generation (lost generation). This condition is likely to occur given the data from the Health Office, Banjar District is one of the largest contributors to short cases in South Kalimantan, and the largest case is found in the working area of Sungai alang puskesmas as much as 41.7\% (2015). Considering that the Alang River region is one of the areas located along the riverbanks and most of the residents' livelihoods are fish farmers, it is therefore necessary to educate these farmers so that the fish obtained are not only sold but utilized by processing fish food by modifying variants based on the menu local fish. One of the methods used so that the knowledge and skills of modifying local fish menus to farmers is effective, so the active learning method using the FTAD (Farmers Team Achievement Division) approach is used. The results of the activities showed that before giving education to farmers most of them had a level of knowledge of less than $63.3 \%$ and after providing education the knowledge of farmers increased to $76.7 \%$ had a level of knowledge of the category quite well. Based on statistical analysis it was stated that by providing education about modifying nutrition menus for families to prevent stunting in children meaningfully by using the FTAD (farmers team achievement division) approach.
\end{abstract}

Keywords: fish farmers, family nutrition menu modification, fish farming center, FTAD

\begin{abstract}
ABSTRAK
Implikasi dari kekurangan gizi yang lama pada baduta dinamakan stunting, dampaknya akan mengalami hambatan pertumbuhan panjang badan/tinggi badan menurut umur dan perkembangan otak sehingga berpeluang kehilangan generasi penerusnya (lost generation). Kondisi ini berpeluang terjadi mengingat data Dinas Kesehatan Kabupaten Banjar merupakan salah satu kabupaten penyumbang kasus pendek terbesar di Kalimantan Selatan, dan kasus terbesar ini ditemukan pada wilayah kerja puskesmas Sungai alang yaitu sebanyak 41,7\% (2015). Mengingat wilayah Sungai Alang salah satu wilayah yang berada didaerah bantaran sungai dan sebagian besar mata pencaharian penduduk adalah petani ikan oleh karena itu perlu memberikan edukasi kepada para petani tersebut agar ikan yang diperoleh tidak hanya dijual saja namun dimanfaatkan dengan mengolah pangan ikan dengan melakukan modifikasi varian menu berbasis ikan local. Salah satu metode yang digunakan agar pengetahuan dan keterampilan memodifikasi menu ikan local pada petani ini efektif maka digunakan metode pembelajaran aktif dengan pendekatan FTAD (Farmers Team Achievement Division). Hasil kegiatan menunjukan bahwa sebelum pemberian edukasi pada petani sebagian besar memiliki tingkat pengetahuan kurang sebesar $63,3 \%$ dan setelah pemberian edukasi pengetahuan petani meningkat menjadi $76,7 \%$ memiliki tingkat pengetahuan kategori cukup baik. Berdasarkan analisis statistic diketahui bahwa dengan pemberian edukasi tentang memodifikasi menu gizi bagi keluarga untuk mencegah stunting pada anak bermakna dengan menggunakan pendekatan FTAD (farmers team achievement division).
\end{abstract}


Kata kunci: petani ikan, modifikasi menu gizi keluarga, sentra budidaya ikan, FTAD (farmers team achievement division)

\section{PENDAHULUAN}

Masalah kurang energi protein (KEP) sebagai salah satu masalah gizi utama yang terjadi pada balita (bawah lima tahun). Implikasi dari kekurangan gizi yang lama pada anak dinamakan stunting. Anak dengan kondisi stunting, kelak akan menjadi manusia dewasa dengan kualitas rendah. Jika kondisi ini terjadi pada anak berumur 0-2 tahun, maka besar kemungkinan anak tidak dapat mencapai tinggi badan potensial yang diharapkan, anak akan mengalami perkembangan otak yang tidak sempurna, sehingga berdampak pada kesulitan dalam memenuhi nilai akademis. Tingkat pendidikan ayah dan ibu merupakan determinan yang kuat terhadap kejadian stunting pada anak. Selain itu, menurut Atmarita, dan Soekirman ternyata selain jenjang pendidikan orang tua, pengetahuan orang tua pun mempengaruhi terjadinya stunting pada baduta (Atmarita dan Soekirman, 2010).

Berdasarkan data riskesdas tahun 2010 pada provinsi Kalimantan Selatan diketahui bahwa sebesar 39,3\% kelompok umur 24-59 bulan masih mengonsumsi energy $<70 \%$ dari kebutuhan minimal energi, konsumsi protein masih $<80 \%$ dari kebutuhan minimal protein adalah $28,0 \%$. Masalah kurangnya konsumsi sejumlah zat gizi ini terjadi sebagian besar pada masyarakat yang memiliki pekerjaan sebagai petani/nelayan/buruh yaitu sebesar $42,7 \%$ untuk konsumsi energi $<70 \%$ dan $42,0 \%$ konsumsi protein $<80 \%$ (Kemenkes, 2010; Hermina \& Prihatini, 2011). Hasil Riskesdas 2013 Provinsi Kalimantan Selatan menemukan bahwa IPKM (Indeks Pembangunan Kesehatan Masyarakat) aspek kesehatan balita sebesar 0,5899 dan IPKM secara nasional sebesar 0,6114. Angka ini menunjukkan bahwa IPKM Provinsi Kalimantan Selatan lebih rendah dibanding IPKM nasional. Salah satu indikator dalam IPKM aspek kesehatan balita yaitu jumlah balita pendek dan sangat sangat pendek. Dari data Riskesdas tersebut diketahui bahwa prevalensi balita yang mengalami pendek dan sangat pendek di Kalimantan Selatan lebih besar 7,03\% dibanding Nasional masing-masing yaitu $44,24 \%$ dan $37,21 \%$. Begitu pula indikator lainnya dalam aspek kesehatan balita seperti prevalensi balita yang mengalami gizi buruk dan gizi kurang lebih besar pula dibanding nasional yaitu sebesar $27,40 \%$ dan $19,63 \%$ atau selisih $7,77 \%$ dan kejadian pendek yang tinggi pada usia 24-36 bulan (41,4\%) (Kemenkes, RI, 2013).

Berdasarkan data Dinas Kesehatan, Kabupaten Banjar merupakan salah satu kabupaten penyumbang kasus stunting terbesar di Kalimantan Selatan, dan kasus terbesar ini ditemukan pada wilayah kerja puskesmas Sungai Alang yaitu sebanyak 41,7\%. Hasil penelitian Rahayu dan Putri di Sungai Alang menemukan sebagian besar balita mengalami stunting sebesar $62,7 \%$ atau sejumlah 79 orang dari 126 balita yang diteliti. Wilayah puskesmas tersebut merupakan wilayah yang terletak pada bantaran sungai merupakan salah satu sentra budidaya ikan, sehingga seharusnya daerah tersebut tidak termasuk dalam kategori daerah dengan masalah kesehatan masyarakat yang sangat buruk dengan prevalensi stunting sebesar $\geq 40 \%$ (Dinkes Kabupaten Banjar, 2013; Rahayu et al., 2016).

Kondisi stunting pada masa balita dapat menyebabkan gangguan perkembangan fungsi kognitif dan psikomotor serta penurunan produktifitas ketika dewasa. Menurut Unicef, bahwa anak stunted berat mempunyai IQ rata-rata lebih rendah 11 poin dibanding IQ anak yang tidak mengalami stunted. Periode dua 
tahun pertama merupakan masa emas untuk pertumbuhan dan perkembangan otak yang optimal, maka perlu upaya perbaikan pendek ketika anak berusia $<2$ tahun. Agar dapat diketahui Potensi Petani ikan dalam Modifikasi Menu Gizi Keluarga Untuk Mencegah Kejadian Stunting pada Balita dengan pendekatan FTAD (Farmers Team Achievement Division). Mengingat sebagian besar jenjang pendidikan ayah kategori rendah sebesar $68,3 \%$ dan pengetahuan ibu didominasi kategori rendah sebesar $77 \%$ (Candra, Puruhita, dan Susanto, 2011; Anindita , 2012; Rahayu et al, 2015; Rahayu et al, 2016). Pendekatan FTAD (Farmers Team Achievement Division) merupakan salah satu metode pemberian edukasi yang mana pendekatan ini dipilih karena paling sederhana dan visiable dibanding pendekatan lainnya, selain itu dengan jenjang pendidikan yang sebagian masih rendah, harapannya FTAD (Farmers Team Achievement Division) dapat dilaksanakan secara terpadu, rutin, dan berkesinambungan di desa Sungai Alang. Pendekatan FTAD (Farmers Team Achievement Division) pada petani ikan di Sungai Alang ini merupakan kegiatan pengabdian masyarakat yang bermitra dengan masyarakat sebagai upaya awal dalam rangkaian yang tidak terpisahkan bagi pemerintah nantinya untuk mengatasi masalah gizi pada balita melalui potensi yang dimiliki oleh petani ikan.

\section{TARGET DAN LUARAN}

Terjadi peningkatan pengetahuan setelah dilakukan edukasi kepada para petani ikan di Wilayah Sungai Alang Kabupaten Banjar

\section{METODE PELAKSANAAN}

Program Kemitraan Masyarakat ini merupakan program pelibatan masyarakat secara aktif dalam upaya pencegahan kejadian stunting pada balita melalui peningkatan pengetahuan tentang knsep stunting, factor penyebab dan cara memodifikasi menu makanan bergizi dengan memanfaatkan potensi makanan local ikan. Dimana sasaran program ini adalah para petani ikan yang berada di wilayah Sungai Alang yang merupakan salah satu sentra terbesar menghasilkan komoditi ikan dengan budidaya karamba/jaring apung di bantaran Sungai Martapura. Para petani ikan diberi edukasi dengan menggunakan pendekatan FTAD (Farmers Team Achievement Division). Adapun jumlah petani ikan yang mengikuti PKM ini sejumlah 30 orang.

Dalam strategi FTAD terdiri atas beberapa tahap. Tahap pertama terlebih dahulu dilakukan survei lokasi dan analisis situasi, tahap kedua pengurusan perizinan agar kegitan PKM berlangsung lancar, tahap ketiga menyamakan persepsi dengan briefing antar tim pengabdian masyarakat dan persiapan bahan dan instrument, tahap keempat mengidentifikasi kelompok petani ikan di Wilayah Sungai Alang Kabupaten Banjar yang memiliki balita, selanjutnya dikelompokkan menurut kejadian stunting (stunting dan tidak stunting), tahap kelima dilakukan koordinasi untuk penentuan lokasi pemberian edukasi dengan kepala desa Sungai Alang, tahap ke enam melakukan evaluasi/identifikasi pengetahuan awal tentang pengolahan ikan yang selama ini disajikan untuk menu keluarga, tahap ketujuh penentuan kelompok belajar. Dalam kelompok belajar ini petani ikan dibekali dan dipandu dengan lembar kegiatan. Selanjutnya untuk mengukur materi yang telah disampaikan ke petani maka dilakukan evaluasi baik dengan quis maupun praktek penyusunan modifikasi menu gizi keluarga berbasis ikan local. Agar semua anggota kelompok petani ikan tetap termotivasi dalam pembelajarannya, maka perlu pemberian penghargaan pada kelompok belajar yang 
anggota kelompoknya memiliki skor tertinggi dalam proses pembelajarannya akan mendapatkan reward atas hasil capaiannya tersebut dan pengumumannya diselenggarakan secara langsung terkait kemampuan pengetahuan maupun praktek penyusunan modifikasi menu gizi berbasis ikan local anggota kelompok belajar. Tahap kedelapan hasil sementara disampaikan kepada kepala desa/petugas kesehatan setempat, tahap kesembilan merupakan tahap analisis untuk mengetahui potensi petani ikan dalam dalam Modifikasi Menu Gizi Keluarga Untuk Mencegah Kejadian Stunting pada Balita dengan pendekatan FTAD (Farmers Team Achievement Division) sebagai bahan untuk persiapan penyelenggaraan desiminasi/laporan.

Adapun Gambaran Iptek yang Akan Ditransfer Kepada Mitra (kelompok petani ikan di Sungai Alang telihat pada Gambar 1.

\section{ALUR POTENSI PETANI IKAN DALAM MODIFIKASI MENU GIZI KELUARGA}

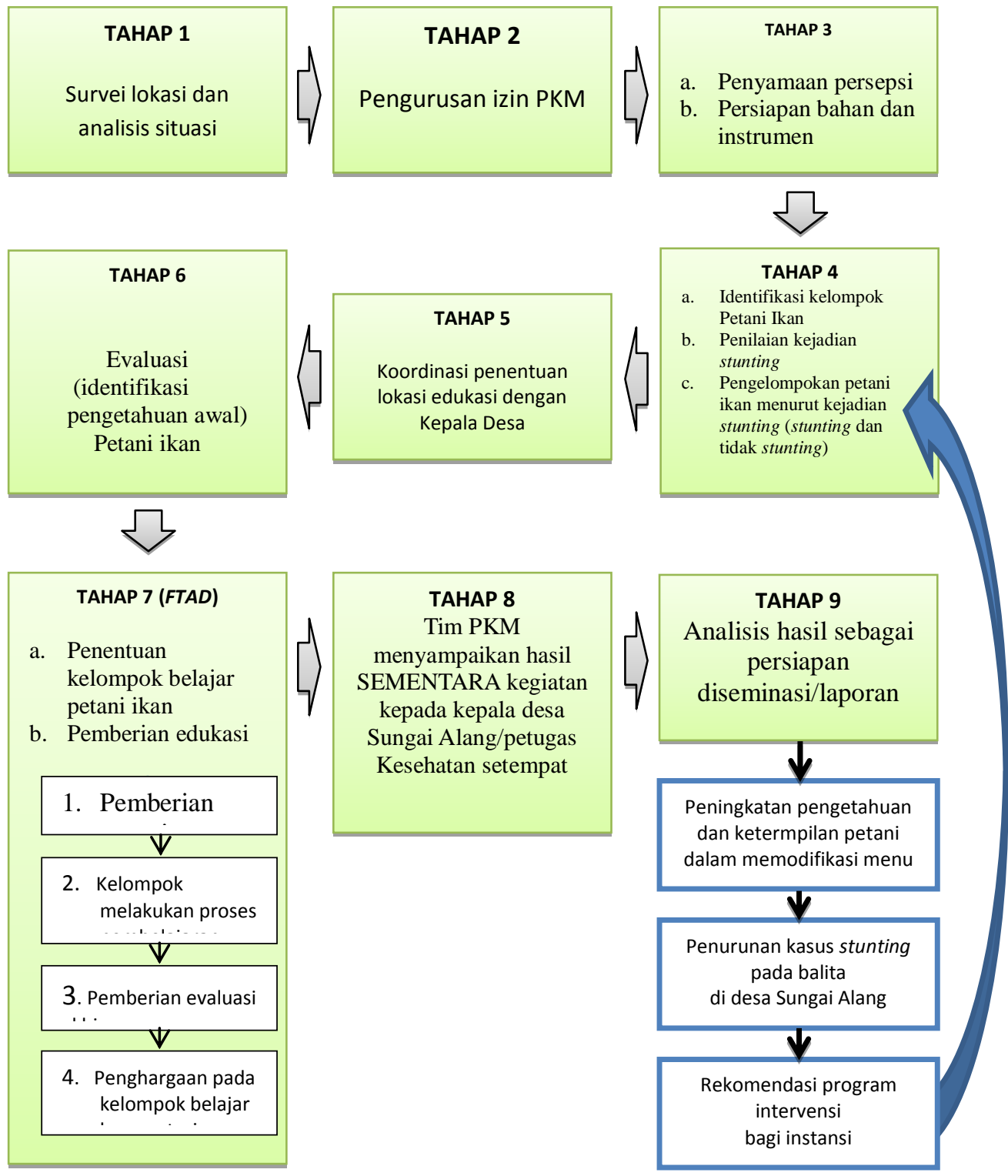

Gambar 1. alur potensi petani ikan dalam modifikasi menu gizi keluarga untuk mencegah kejadian stunting - 1 - L-1:_. 


\section{HASIL DAN PEMBAHASAN}

Pemberian edukasi kepada petani ikan di Sungai Alang telah dilakukan, namun kegiatan tersebut dilakukan sebelum diberikan pretest untuk mengetahui pengetahuan awal petani ikan terhadap stunting,factor penyebab maupun cara memodifikasi menu makanan bergizi yang beermanfaat bagi pencegahan stunting pada balita. Untuk mengetahui data detail distribusi pengetahuan menurut kategori tingkat pengetahuan ketika dilakukan pretest dapat dilihat pada Table 1 .

Tabel 1. Distribusi Frekuensi Pengetahuan Petani Hasil Pre-Test

\begin{tabular}{cccc}
\hline \multicolumn{2}{c}{ Kategori Nilai } & Hasil & Persentase \\
\hline Kurang & $<50$ & 19 & $63,3 \%$ \\
Cukup Baik & $\geq 50$ & 11 & $36,7 \%$ \\
Total & & 30 & $100 \%$ \\
\hline \multicolumn{2}{c}{ Sumber: Data Primer, 2018 }
\end{tabular}

Tabel 1 menunjukkan bahwa sebelum dilaukan edukasi pada petani ikan, sebagian besar petani ikan memiliki tingkat pengetahuan kategori kurang yaitu sebesar 63,3\%. Pengetahuan kurang ini berkaitan dengan masih kurangnya informasi yang diketahui petani tentang stunting, faktor penyebeb serta memodifikasi menu makanan tingkat keluarga supaya dapat mencegah balita mengalami stunting. Setelah mengetahui distribusi tingkat pengetahuan petani ikan, maka selanjutnya dilakukan pemberian edukasi terhadap para petani ikan di Sungai Alang tentang stunting, faktor penyebab maupun cara memodifikasi menu makanan bergizi yang bermanfaat bagi pencegahan stunting pada balita. Namun untuk mengukur sejauhmana perubahan tingkat pengetahuan setelah diberikan edukasi terkait dngan materi tersebut pada para petani ikan, maka dilakukan post test. Adapun hasil posttest dapat dilihat pada Tabel 2 .
Tabel 2. Distribusi Frekuensi Pengetahuan Petani Hasil Post-Test

\begin{tabular}{cccc}
\hline \multicolumn{2}{c}{ Kategori Nilai } & Hasil & Persentase \\
\cline { 3 - 4 } & & & \\
\hline Kurang & $<50$ & 7 & $23,3 \%$ \\
Cukup Baik & $\geq 50$ & 23 & $76,7 \%$ \\
Total & & 30 & $100 \%$ \\
\hline
\end{tabular}

Sumber: Data Primer, 2018

Tabel 2 menunjukkan bahwa setelah diberikan edukasi kepada petani ikan tentang stunting, faktor penyebab serta cara memodifikasi menu makanan bergizi yang diperuntukkan bagi pencegahan balita stunting mengalami peningkatan sebesar $40 \%$ yaitu tingkat pengetahuan petani yang sebelumnya kategori kurang sebesar $63,3 \%$ menurun menjadi $23,3 \%$.

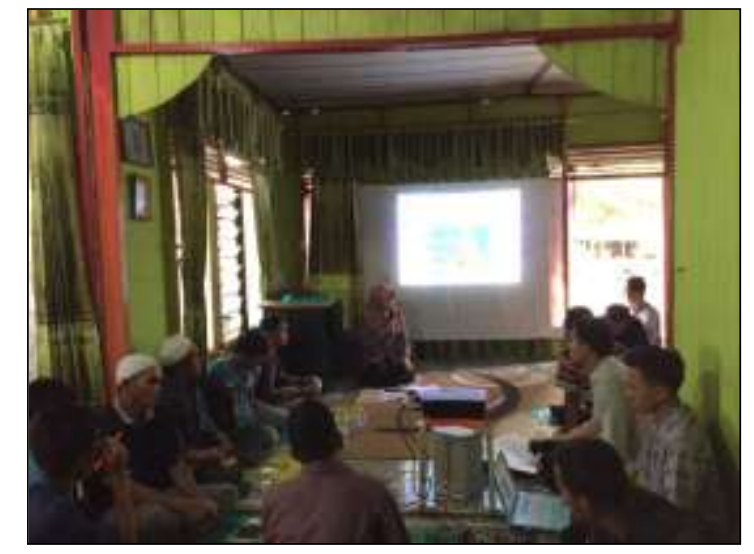

Gambar 2. Pemberian materi

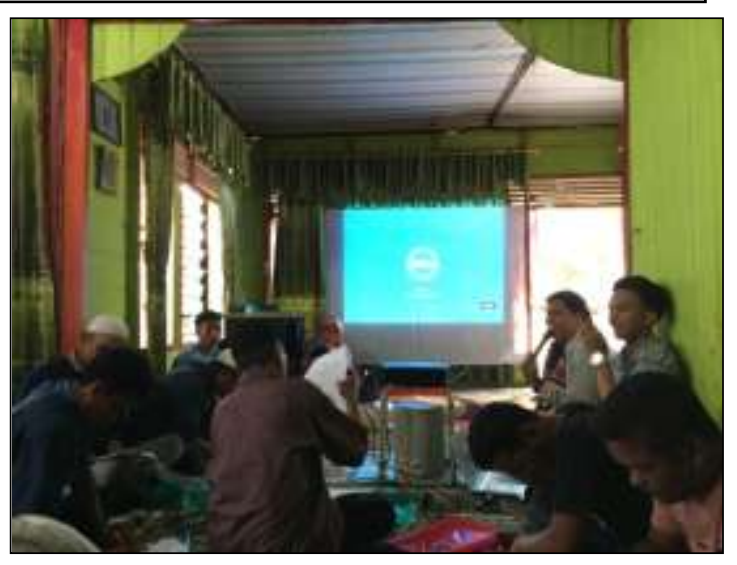

Gambar 3. Response dari peserta 
Perbedaan Pengetahuan Sebelum dan Sesudah diberikan edukasi

Analisis bivariat yang dilakukan adalah uji statistik wilcoxon karena data tidak berdistribusi normal. Uji wilcoxon digunakan untuk mengetahui perbedaan tingkat pengetahuan antara sebelum dan sesudah dilakukan intervensi pemberian edukasi gizi bagi petani ikan, maka dilakukan uji statistic menggunakan Wilcoxon. Adapun hasil uji statistic pada Tabel 3.

\section{Tabel 3.Hasil Uji Statistik Wilcoxon Perbedaan Peningkatan Pengetahuan antara Sebelum dan Sesudah Intervensi pemberian edukasi gizi bagi petani ikan Test Statistics ${ }^{b}$}

Test Statisticsb

\section{HASIL_POSTTEST_HASIL_PRE TEST}

Z

$$
-3.596^{\mathrm{a}}
$$

Asymp.

.000

Sig. (2-

tailed)

a. Based on negative ranks.

\section{b. Wilcoxon Signed Ranks Test}

Hasil uji tersebut menunjukkan bahwa $p$-value $=0,000$ atau $0,001<0,005$ yang artinya H0 ditolak yaitu ada perubahan yang signifikan pemberian edukasi gizi terhadap peningkatan pengetahuan petani terkait stunting, factor penyebab serta cara memodifikasi menu makanan bergizi untuk mencegah balita mengalami stunting. Keberhasilan dalam merubah tingkat pengetahuan petani ikan dari sebelumnya kategori tingkat pengetahuan paetani lebih banyak didominasi kategori kurang sebesar $63,3 \%$ menurun menjadi $23,3 \%$. Ini berarti bahwa kategori tingkat pengetahuan cukup baik bertambah dari sebelum pemberian edukasi sejumlah $36,7 \%$ meningkat menjadi $76,7 \%$. Peningkatan tingkat pengetahuan pada petani ikan ini salah satu faktor yang mempengaruhi adalah pendekatan yang digunakan dalam pemberian edukasi.

$$
\text { Pemberian edukasi ini }
$$

menggunakan metode pendekatan FTAD (Farmers Team Achievement Division). Pendekatan ini menyesuaikan dengan karakteristik petani salah satu diantaranya adalah karena jennang pendidikan petani ikan lebih didominasi oleh pendidikan rendah sebesar 68,3\%. Menurut hasil penelitian sebelumnya bahwa pendekatan FTAD memberikan peluang cukup besar merubah pengetahuan para audiensnya Pendekatan FTAD (Farmers Team Achievement Division) merupakan salah satu metode pemberian edukasi yang mana pendekatan ini dipilih karena paling sederhana dan visiable dibanding pendekatan lainnya, selain itu dengan jenjang pendidikan yang sebagian masih rendah(Candra, Puruhita, dan Susanto, 2011; Anindita , 2012).

Pembelajaran FTAD merupakan pembelajaran yang melibatkan aktif anggota-anggota kelompoknya agar turut serta berpartisipasi baik dalam pembahasan stunting, factor penyebab maupun cara memodifikasi menu makanan bergizi menggunakan potensi local berupa ikan di wilayah Sungai Alang. Selain itu, pemberian evaluasi terhadap masingmasing kelompok kerja turut berperan dalam perubahan tingkat pengetahuan ini karena masing-masing anggota kelompok termotivasi untuk lebih baik dari anggota kelompok yang lain begitupun motivasi antar kelompok agar lebih baik dari kelompok lainnya. Evaluasi ini dilakukan dapat berupa quis maupun praktek penyusunan modifikasi menu gizi keluarga berbasis ikan local untuk mengetahui sejauh 
mana materi yang telah diberikan telah diterima oleh kelompok belajar petani.

Partisifasi aktif oleh anggota kelompok ataupun masing-masing kelompok kerja tidak lepas pula dari adanya tahap pemberian penghargaan kepada anggota kelompok maupun kelompok belajar yang paling aktif ketika kegiatan FTAD berlangsung. Dimana pemberian penghargaan ini dilakukan dengan menghitung skor peningkatan kemampuan pengetahuan maupun praktek penyusunan modifikasi menu gizi berbasis ikan local anggota kelompok belajar. Bagi anggota kelompok yang memiliki skor tertinggi akan diumumkan secara langsung dan diberikan reward atas capaian yang telah diperolehnya.

\section{KESIMPULAN DAN SARAN}

\section{A. Kesimpulan}

Masih ditemukan petani ikan yang memiliki tingkat pengetahuan berkategori kurang sebesar 23,3\% setelah pemberian edukasi menggunakan pendekatan FTAD dan $m$ Masih ditemukan petani ikan yang memiliki tingkat pengetahuan berkategori cukup baik hanya sebesar $76,7 \%$, meski setelah mendapat edukasi dengan menggunakan pendekatan FTAD. Berdasarkan analisis statistic diketahui bahwa ada perubahan yang signifikan pemberian edukasi gizi terhadap peningkatan pengetahuan petani terkait stunting, faktor penyebab serta cara memodifikasi menu makanan bergizi untuk mencegah balita mengalami stunting dengan $p$-value $=$ $0,000$ ( $p$-value $<0,05)$.

\section{B. Saran}

Diharapkan kepada petani ikan khususnya di Sungai Alang untuk meningkatkan pengetahuan tentang stunting, factor penyebab maupun cara memodifikasi menu makanan bergizi menggunakan potensi local berupa ikan di wilayah Sungai Alang untuk mencegak kejadian stunting pada balita. Diperlukan upaya kerjasama antara pihak institusi kesehatan, kelautan perikanan, pendidikan, tim penggerak PKK untuk menyelenggarakan intervensi program gizi mengingat permasalahan stunting pada balita cenderung bertambah, tidak saja di lingkup kabupaten/kota, provinsi namun menjadi masalah nasional.

\section{DAFTAR PUSTAKA}

Anindita P. Hubungan tingkat pendidikan ibu pendapatan keluarga, kecukupan protein, dan Zinc dengan stunting pada balita usia 6-35 bulan di kecamatan Tembalang Kota Semarang. 2012. Jurnal Kesehatan Masyarakat: 1 (2).

Atmarita. (2010) Masalah generasi penerus bangsa saat ini di Indonesia: Kurang gizi, kurang sehat, kurang cerdas. Disampaikan pada Seminar Nasional "Optimilisasi Potensi Baduta Stunted" di Indonesia Universitas Gajah Mada, 2 Oktober 2010: Yogyakarta

Candra A, Puruhita N, Susanto JC. Risk factors of pendek among 1-2 years old children in Semarang City. 2011. M Med Indonesiana; 45(3):206-12.

Dekkar, L.H., Plazas, M.M., Bylin, C.M.A \& Villamor, E. (2010) Pendek assosiated with poor socioeconomic and maternal nutrition status and respiratory morbidity in Colombian schoolchildren. Food and Nutrition Bulletin. 31: 2 
Dinkes Kabupaten Banjar. Profil Kesehatan Kabupaten Banjar tahun 2013; Kabupaten Banjar

Hermina \& Prihatini. 2011. Gambaran keragaman makanan dan sumbangan terhadap konsumsi energi protein pada baduta baduta pendek (Pendek) di Indonesia.. Jurnal Litbangkes, Kemenkes RI; 39: 62-73.

Kemenkes RI. (2010) Laporan Riskesdas 2010. Badan Penelitian dan Pengembangan Kesehatan: Jakarta

Kemenkes RI. (2013) Laporan Riskesdas 2013. Badan Penelitian dan Pengembangan Kesehatan: Jakarta

Rahayu, A., Yulidasari, F., Putri, A.O, Rahman, F., dan Rosadi, D. Faktor risiko yang berhubungan dengan kejadian pendek pada anak usia 6-24 bulan. 2016. Jurnal Kemas; 11 (2): 96-103

Rahayu, A., Yulidasari, F., Putri, A.O, dan Rahman, F. 2015. Riwayat Berat Badan Lahir dengan Kejadian Stunting pada Anak Usia Bawah Dua Tahun. 2015. Jurnal Kesehatan Masyarakat Nasional; 10 (2): 67-73

Rahayu, A., Yulidasari, F., Khairiyati, L., Rahman, F dan Anhar, V.Y. 2016. The risk factor of mother's nutrition Knowledge level related to stunting in Public health center region cempaka, Banjarbaru city. International Journal of Applied Business and Economic Research; 14 (10): 6999-7008

Rosha BC, Hardiansyah \& Baliwati YF. 2012. Analisis determinan pendek baduta 0-23 bulan pada daerah miskin di Jawa Tengah dan Jawa Timur. Jurnal. Jakarta: Panel Gizi Makanan; 35(1): 34-41.
WHO. (2011) Indicator for assessing infant and young child feeding practices. Geneva: WHO Press. 